\title{
Green Accounting and Management for Sustainable Manufacturing in Developing Countries
}

\author{
Sherine Farouk ${ }^{1}$, Jacob Cherian ${ }^{2} \&$ Jolly Jacob ${ }^{3}$ \\ ${ }^{1}$ Department of Accounting, College of Business Administration, Abu Dhabi University, Abu Dhabi, UAE \\ ${ }^{2}$ Department of Management, College of Business Administration, Abu Dhabi University, Abu Dhabi, UAE \\ ${ }^{3}$ Department of Applied Sciences and Mathematics, College of Arts and Sciences, Abu Dhabi University, Abu \\ Dhabi, UAE \\ Correspondence: Jacob Cherian, Department of Management, College of Business Administration, Abu Dhabi \\ University, P.O Box 59911, Abu Dhabi, UAE. Tel: 971-501-5646. E-mail: jacob.cherian@adu.ac.ae
}

Received: May 16, 2012 Accepted: July 23, 2012 Online Published: October 16, 2012

doi:10.5539/ijbm.v7n20p36 URL: http://dx.doi.org/10.5539/ijbm.v7n20p36

\begin{abstract}
This article is located within a broad body of literature concerned with environmental accounting and critical of the current role of accounting. The main purpose of this paper is to analyze the available literature based on the Environmental accounting (green accounting) and sustainability and to understand how it has been studied and evaluated by different authors who are working in this area. Current literature focuses on environmental sustainability and lacks quantitative ways to make capital budgeting decisions. The study suggests that there should be wide empirical studies in this area so that, through the environmental accounting system we can analyze the environmental performance of each companies or organizations. A possible conceptual model for environmental accounting and reporting by Michael John Jones is also suggested in this article. The study concludes that Environment Management Accounting can likely support decision making in companies towards better environmental performance today, through structured cost assessment that support effective decision making, and future proofed product mixes, strategies and investment.
\end{abstract}

Keywords: green accounting, environmental accounting, sustainability accounting, conceptual model, accounting

\section{Introduction}

Green accounting is considered to be an important tool for understanding the influential aspects of natural environment with respect to the economy. The data and information provided by environmental accounts are determined to be in relation to the involvement of natural resources in economic development and costs occurred due to pollution or resource degradation. The advantage of corporate environmental accounting initiative is identified as the ability to determine and create awareness regarding costs related to environment, which in turn helps in identifying the techniques for reducing and avoiding costs of such type. Due to this advantageous feature, the performance of the environment has also been improved. The environmental costs that occur due to the financial outcomes of the firm's operation can be determined by means of a green accounting tool. The operational performance of the organization can be determined with the help of certain process like documentation and reporting the emissions of green house gases (GHG). However, the conventional accounting system is determined not to be considered for new or existing demands for natural resources. This demand on natural resources may destabilize sustainability of economic performance and growth, depletion of natural capital, environmental degradation as a social cost of economic activity and also the account of nonmarket goods in gross domestic product (GDP).

Aronson and Lokfgren (1999) make the argument that society recommends for the environmental responsible behavior from both government and business concerns by examining the ecological disasters and degradation of earth's ecosystem. It is a general fact that expected results will be obtained when the business managers are given the responsibility for solving the ethical problems by considering either promoting their profit or preserving the environment. Hence there should be standardized and quantitative measures in order to control the business activities polluting the environment before implementing a condition in which the business organization 
are forced to clean the pollution made by them (Stanovic, 2010).

As most of the damages cannot be restructured, it is best to prevent it rather than avoiding. Asheim (1997) suggests the establishment of green or environmental accounting system is in order to prevent the pollution or damages. The system considers the economic measures that have an impact on power production and consumption on environment. Due to the process the power plant that affects the natural capital highly is considered and corresponding actions required are conducted. Rubenstein (1992) suggests that ethical problems can be solved when the environmental stewardship is put in terms of financial manner, and which attains more importance from the business.

The importance of the environmental problems has been increased due to the continuous degradation of environment and increasing environmental disasters. Lafontaine (2002) makes the argument that in order to involve environmental problems in normal life it is essential to consider them with respect to economic, legal, accounting, financial and technical levels. Considering the environmental aspects in terms of economy such as costs of services and products, the organizations are able to reduce the consumption of natural resources leading to save in greater extent and address the environmental compliance consumer health requirements. In order for the entity to undertake the responsibility one has to experience the legal consideration of the risks involved in the environment. The main source for the responsibility is due to the failure in obeying the environmental legislative resulting to administrative sanctions. Betianu (2008) suggested that the performance of the work can be measured by means of documenting environmental costs and identifying environmental costs with respect to accounting and financial perspective and their association with financial disclosure.

Hence in the modern business world the implementation of green accounting is considered to be an important factor. But the demerit identified with respect to green accounting system is the lack of appropriate implementing techniques. Saving environment and developing the economy is a challenging feature for developing countries. The organizations that are determined to be in the field of or related to Energy-reliant manufacturers and power generating utilities are measured to be under more pressure with respect to implementing green accounting. At the same time firms from all business sectors are assumed to be implementing green accounting tool to a certain extent in the upcoming years.

\subsection{Objectives}

The main purpose of the paper is to examine the literatures that deals with Environmental accounting or green accounting and sustainability. The study also makes an attempt to understand how green accounting has been considered and evaluated by different authors who have done researches in the same field. Based on different studies considered, a procedural model suitable for most of the developing countries is to be selected.

\section{Literature Review}

The section examines various studies that are dealt at international and national levels with respect to Environmental and sustainable development.

Gary Otte (2008) suggested in the article of 'GHG Emission Accounting' that the organizations may have certain internal and external benefits by means of implementing green accounting system. He declares that GHG accounting emission involves, tracking emissions, accounting and reporting. The communication process between suppliers and firms may be developed by implementing GHG accounting which would lead to reduction of costs. The study also expresses the techniques used for GHG calculation by means of explaining the five steps. It has been declared that green accounting also involves certain limitations and barriers. Certain solutions have been provided by the author in order to compensate for the barriers. The author's point of view is that the organization can reduce the costs and experience certain beneficiary factors related to environment.

Heba Y M \& Yousuf (2010) examined the concepts of environmental accounting by exploreing the techniques to develop the environmental reporting that enables the government to utilize and making businesses more responsible for their externalities. Moreover, as the consideration for the environmental accounting increases, there is a parallel increase in measuring the environment performance (Yajhou and Doreweiler, 2004). In this study the integration of environmental and business policy has been considered to a great extent. The author reveals that the public's consideration for the environmental accounting and government led incentive based regulation are the main reason for the study. In upcoming years the companies will be facing challenges with respect to establishing and implementing business strategies that are concerned with environmental accounting.

International Union for Conservation of Nature (IUCN) (2003) detailed the introduction of environmental accounting in brief in their booklet 'Environment Accounting: What's it all about'. The environment and system of National Accounts are discussed in the first part of the study. The advantages of Environmental accounting 
with respect to the existing system of National Accounts have been declared in the section. Harazain and Horváth (2011), in the article 'Relation between Environmental Accounting and Pillars of Sustainability' described four challenges related to sustainable development. The main objective of the study is to provide an appropriate solution for the question: is it true that social and integration point of view is outside of the concept environmental accounting? With the help of literature review and primer research, the author was able to conclude that the environmental accounting is not beyond the social and integration challenges of sustainability.

With the help of the article 'Green accounting methodology for India and its states' Haripriya (2008), was able to determine the importance of green accounting. They have described that the existing GDP accounting system will result in unsustainable development. The main reason why the author suggested for green accounting framework is due to the fact that the existing GDP developments reduce the measure of economic growth rather than measuring national wealth. The current paper also tends to differentiate the traditional GDP and green accounting apart from the demerits of existing GDP can be compensated by green accounting methodology.

A balance set of financial and nonfinancial measures are essential for the managers in order to make successful decisions (Moller and Schaltegger, 2008). The aspects considered by such measures are various requirements, strategic goals, strategies, resources, capabilities, and casual relation between these domains. The association between sustainability balanced scorecards and eco-efficiency analysis are detailed in the paper. The organization can be made more sustainable and reliable by means of implementing the sustainability accounting tool (Bent and Richardson, 2003).

A report was published by United Nations Division for Sustainable Development (UNDSD) (2001) and was titled as 'Improving the Role of Government in the Promotion of Environmental Management Accounting (EMA)'. The report was published in order to describe certain principles and procedures related to Environmental Management Accounting, focusing particularly on techniques to quantify environmental costs for the development of national EMA guidelines and framework. According to this report, both conventional cost accounting and non environmental costs of the accounts are assumed to be hidden with respect to management. It has also evidentially proved that the management of the organization has underestimated the development and extent of such costs.

A proposal has been made by the Department of Economic and Social Affairs in Statistics Division (ESASD) of United Nations (UN) in order to establish a comprehensive system of economical and environmental national accounts in association with the World Bank's environment department. According to the proposal, Millennium Ecosystem Assessment (MEA) determines the main reason for the issue to be failure of the value ecosystem services and also declares that environmental accounts may include better policy. The manager and policy makers despite their experience at governance consider the environmental and economic accounts to be complex. With the help of environmental accounts, countries are able to monitor the process of providing a sound basis for policy interference and reliability with sustainable development at each stage.

Arroyo (2006) in the article titled as 'The three dimensions of a sustainable management accounting system' suggested that the traditional role of management accounting system has been determined to be complex due to certain factors mainly identification, classification, measurement and reporting of environmental and social information for the past few years.

The work of Lehman (2011) establishes the art of interpretation to management accounting, to be a way to think about the natural world. The main objective of Interpretive Accounting Research (IAR) has been determined to be influenced by the desire to understand how accounting disciplines like management accounting are related to existing issues like global warming, carbon emissions and sustainability considerations. The issue for management accountants is to keep in mind the need to broaden and conceptualize how we theorize cultural and environmental dilemmas that confront the discipline. The art of interpretation with respect to accounting research is a technique that highlights responsibilities to our shareholders and the natural world. The report of International Federation of Accounts (IFA) (2005) on EMA evaluates the physical and monetary accounting process of EMA. The association between material balances, material flow accounting and physical environment performance indicators (EWPIs) are detailed in the physical accounting section. Over the past few years, sustainability was incorporated with policy statements of various organizations (Jasch and Stasiskiene, 2005).

Bailey (1995), in his case study reported that the developing process of Green Accounting in AT\&T's is based upon the definition provided by AT\&T in July, 1995. According to AT\&T, Green Accounting is defined to be "identifying and measuring AT\&T's costs of environmental materials and activities, and using this information for environmental management decisions." The perspective of AT\&T is represented by concepts, terms and approach and the perspectives of the US Environmental Protection Agency (EPA) are not considered in the 
article. Further, the case study illustrates about how the AT\&T, a multinational high technology organization has initialized the implementation of Green Accounting.

The importance of "Performance Measurement Systems" including balanced cards as environmental management measures has been investigated by Lansiluto and Jarvenpaa (2010). In their article on Greening the Balanced Score Card, they discuss the importance of factors which support and ensure that the performance measurement systems can incorporate metrics to identify with better environmental measures. The change of the performance measurement systems should be in a manner that the culture of the company is considered before suggestions are implemented. The study also identified that environmental challenges in the performance measurement systems can be identified in a better manner if balanced score cards are implemented.

A compound manifold theoretical framework was presented by Jones (2010) to identify the measures related to accounting of environmental issues and issuing reports in a manner, to ensure in terms of corporate responsibility, associating it between the type of industry and environment, impact of industry on the environment and voluntary disclosure.

The drive towards sustainable reporting was identified by Ambe (2009). He reported the legislative conventions which govern the internal decisions taken by a company in terms of generation and documentation of energy output from material, its resultant flow; the generation of waste from the end product was quite evident. In contrast when monetary issues were considered in terms of environmental accounting it was observed that the cost, profit and the savings of the company were together. The legislations as presented by Monetary Environmental Management Accounting (MEMA) in association with rehabilitation, decommission, restoration and production costs were observed in the mining and petrochemical industries. The examined case study in this regard presents the evidence of information on environmental management.

An effective environmental management accounting system presents the concepts of sustainable accounting with regards to cost measurement, $\mathrm{d}$ social aspects and its ultimate value in addition to the corporation was identified by Cullen (2010) in his conceptual model; Sustainability Management Accounting System (SMAS). This model presented efficient cost allocation measures to create better measures of cost accounting which would ultimately enable the management to arrive at decisions and present better disclosure. In his paper titled Theoretical Framework for Environmental Accounting- Application on the Egyptian Petroleum Sector'. Hamid (2002) identified a framework of environmental accounting which covered issues relating to environment, ecology, natural resources and green accounting. His paper presented the latest concepts and definitions related to green accounting as well as identified the need for environmental accounting measures. Further, his study concludes on the idea that traditional measures of accounting do not take into account sustainable development measures and policies required for promoting better environment safety but delves into economic aspects only.

\section{Discussion}

This paper identified the various literature associated with environmental accounting and sustainable practices. The ultimate aim of the same is to present varying views associated with environmental management and accounting measures which helps in arriving at a decision making tool for companies to implement sustainable accounting measures and thereby present better environmental performance. From the study it can be concluded that empirical research in the field of green accounting is relatively less with most of them being qualitative in nature. From the results of the present study one can conclude that the establishment of an accounting system which has been tested empirically will enable the identification of environmental performance of different companies and organizations. Current literature centers on sustainability without presenting concrete measures by which budgeting decisions can be made by organizations. Majority of the author's present qualitatively possible development measures for arriving at indices related to lifecycle production and organizational sustainability related factors. The implementation of these indices may help arriving at levels of sustainability for businesses. There is room to develop tools, which link the profitability from sustainability, to evaluate project acceptance.

The maintenance of productivity, diversity, balance in eco system and equity across generations is directly linked to decision making processes which encompass business, social and environmental procedures of the company. This management system implemented by organizations is called as sustainable management. Sustainable accounting benefits over traditional measures as it takes into account the different externalities which are in place. In this type of accounting the cost-benefit ratio in terms of risk control, adjustment costs, overhead costs and disclosure notes can be identified in an effective manner so as to present better sustainable practices.

The importance of sustainable accounting is found to be linked to greening of national income accounts by integrating sustainability and valuation of ecosystem. The assessment of performance of a country in relation to 
others is often presented by national income as they present the main foundation of information with regards to current status of the country's economy. This income account however presents a number of pitfalls associated with treatment of environment. The increasing government and consumer pressure has increased the environmental cost and future internalization of costs for external effects. Overhead accounts are identified to be filled with costs of electricity if it is recorded and regularised. This review identifies that analysis and discussion of possible sustainable accounting measures is found to be associated with decision making aspects relating to monetary measures, cost, revenue, cash flow, the related flow of energy and the energy related costs. To enable this it is important in implementing the Environmental Management Accounting (EMA) which helps in presenting a decision making systems for corporations with regards to measures promoting better performance environmentally by identifying effective cost assessment structures. Hence, these measures ensure that future products of organizations help in presenting better product mixes, strategies and investments.

\subsection{Important Points towards Building a Conceptual Model}

A conceptual model is sorely required in order to form framework over which regulations and rules can be developed and implemented towards making the industry more eco-friendly. The literature review presents a number of models. There are a number of aspects that a model has to incorporate in its framework. Some of these aspects are the responsibility of the firms towards the environment, the dangers posed to the environment, the relationship and impact of the industries on the environment and the measurement of the impact of industries on the environment. The conceptual model can include aspects of other models that have previously been researched by various authors. For example Heba Y M and Yousuf (2010), examined the concepts of environmental accounting. In their study they explored the techniques to develop the environmental reporting concept that would enable the government to utilize the concept and make businesses more responsible for their externalities. The techniques they used would be beneficial when it comes to measuring the environmental impact. Cullen's (2010) model presented efficient cost allocation measures to create better measures of cost accounting which would ultimately enable the management to arrive at decisions and present better disclosure. Some of these models were used as a base for developing a proper model that is presented in the next section.

\subsection{Conceptual Model}

This article is presented in relation to a broad body of literature which is concerned with environmental accounting measures. From the evidences collected from prior literature it can be observed that a multilayered model which has eight different indices is identified. This model aims at presenting justifications related to environmental accounting and reporting practices. The aim of this model is to present a novel view of the different factors associated with environmental accounting without denying the possible impact that other models have. This model also aims at presenting debates related to the identification of corporate attitude towards environmental sustainability.

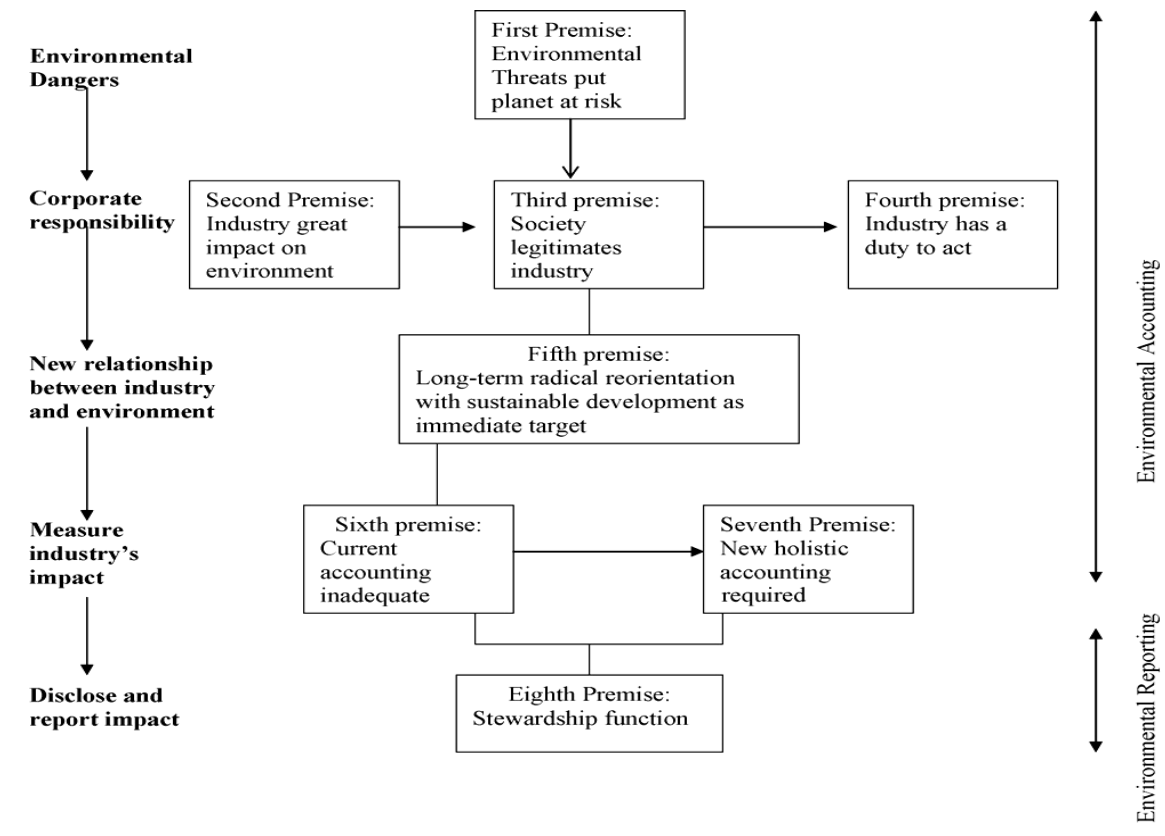

Figure 1. A possible conceptual model for environmental accounting

Source: Michael John Jones (2010) 


\section{Conclusion}

The current paper has delved into the various ways in which different researchers have carried out their respective researches in relation to environment accountability and sustainability. Limited literature is available on social and environmental accounting in emerging and developing nations when compared to their western counterparts. In the case of emerging and under developed nations, their socio economic realities are quite different as are the corporate motivations for undertaking social and environmental accounting. Accountants and managers may not accept the fact that projects that are in violation of critical ecological functions will not be approved even if they are quite profitable and efficient. Managers who are more environmentally inclined will persuade clients to accept responsibility for a bigger share in their participation when it comes to global clean-up activities. The internal accountants will be made to work in tandem with the environmental engineers in a bid to teach them the methodologies involved in environmental accountability and the statistical techniques needed to measure compliance with the environmental regulations.

The article developed a multilayered theoretical framework to underpin environmental management (severe environmental dangers; corporate responsibility; new relationship between industry and environment; measure industry's impact and disclose and report impact) thereby presenting a model for green accounting. The model was developed from a personal conviction that companies should make an attempt to ensure that environmental issues are addressed. The model also strived to be realistic by recognizing the political and social realities of the current scenario. This particular model is not meant to be exclusive or a measure which is more effective than other theoretical models. However, it is one model by which environmental progress can be measured.

The contribution of this paper and other academic work in green accounting does not completely embrace the views of the business world while at the same time it does not present radical views which cannot be implemented in any real world scenario. The paper makes an attempt to point out that there is a need for a great deal of sensitivity towards how green accounting practices are carried out and how their needs are to be valid and feasible critical theoretical policy prescription. The researcher feels that future research should be presented in a manner that academicians are completely sensitive to approaches related to green accounting promotion and mobilize risks so that the problems of contemporary green accounting practices are recognized and a viable instrument is developed keeping in mind all sensitivity issues.

\section{References}

Abdel-Rahim, Heba Y. M., \& Yousef M. Abdel-Rahim. (2010). Green accounting - a proposition for EA/ER conceptual implementation methodology. Journal of Sustainability and Green Business, 5(1), 27-33.

Adams, C. A. (2002). Internal organisational factors influencing corporate social and ethical reporting: beyond current theorising. Accounting, Auditing \& Accountability Journal, 15(2), 223-50. http://dx.doi.org/10.1108/09513570210418905

Adams, Carol, A., \& Patty McNicholas. (2006). Making a difference Sustainability reporting, accountability and organisational change. Accounting, Auditing \& Accountability Journal, 20(3), 382-402. http://dx.doi.org/10.1108/09513570710748553

Ambe, Cosmas, M. (2009). Linkages of Sustainability and Environmental Management Accounting. Innovation for Sustainability in a Changing World, 2, 73-84.

Arroyo, Paulina. (2006). The Three Dimensions of A Sustainable Management Accounting System. Journal of Management Accounting Research, 13, 47-90.

Asheim, G. B. (1997). Adjusting green NNP to measure sustainability. The Scandinavian Journal of Economics, forthcoming. http://dx.doi.org/10.1111/1467-9442.00068

Bailey, Paul. (1995). Environmental accounting case Studies: Green accounting At AT\&T' (3rd ed.). Los Angeles: SAGE Publications, Inc.

Bennett, M., \& James, P. (1997). Environmental-related management accounting: current practice and future trends. Greener Management International, 17, 33-51.

Bețianu, L. (2009). Calitate totală în contabilitatea mediului. Universității, Alexandru Ioan Cuza, Publishing House, Iaşi.

Burnett, Royce, D., \& Don R. H. (2008). Ecoefficiency: Defining a role for environmental cost management. Accounting, Organizations and Society, 33, 551-581. http://dx.doi.org/10.1016/j.aos.2007.06.002 
Cullen, D. (2010). Sustainability Management Accounting System (SMAS): Towards a Conceptual Design for the Manufacturing Industry. Journal of Business \& Economics Research, 4(10), 1-4.

Daniel Blake Rubenstein. (1992). Bridging the gap between green accounting and black ink. Accounting. Organizations and Society, 17(5), 501-508. http://dx.doi.org/10.1016/0361-3682(92)90044-S

Gray, R., Javad, M., Power, D. M., \& C. Sinclair, D. (2001). Social and Environmental Disclosure and Corporate Characteristics: A Research Note and Extension. Journal of Business Finance \& Accounting, 28(3), 327-56. http://dx.doi.org/10.1111/1468-5957.00376

Gundimeda, Haripriya et al. (2008). Green Accounting Methodology for India and its States. Green India States Trust, 6, 23-42.

Hamid, Mohamed, A., \& Raouf, A. (2002). Theoretical Framework for Environmental Accounting- Application on the Egyptian Petroleum Sector. Ninth Annual Conference of the Economic Research Forum (ERF), Cairo, Egypt.

Harazin, P., \& Horváth, Gy. (2011). Relation between Environmental Accounting and Pillars of Sustainability. World Academy of Science, Engineering and Technology.

Hecht, Joy E. (2000). Lessons Learned from Environmental Accounting: Findings from Nine Case Studies. IUCN - The World Conservation Union, 42, 1-48.

Hopwood, Anthony, G. (2009). Accounting and the environment. Accounting, Organizations and Society, 34, 433-439. http://dx.doi.org/10.1016/j.aos.2009.03.002

International Federation of Accounts. (2005). Environmental Management Accounting. International Guidance Document, 3, 1-92.

Jasch, C., \& Zaneta S. (2005). From Environmental Management Accounting to Sustainability Management Accounting. Environmental research, engineering and management, 4(34), 77-88.

Jones, Michael John. (2010). Accounting for the environment: Towards a theoretical perspective for environmental accounting and reporting. Accounting Forum, 34, 123-138, http://dx.doi.org/10.1016/j.accfor.2010.03.001

Lafontaine, J. P. (2002). Enseignement et management de l'information: le cas de la comptabilite environnementale. XXIII congres de l' AFC, Toulouse.

Lansiluoto, A., \& Marko J. (2010). Greening the balanced scorecard. Science Direct. Business Horizons, 53, 385-395. http://dx.doi.org/10.1016/j.bushor.2010.03.003

Lehman, Glen. (2011). The Management of Sustainability: The Art of Interpretation. JAMAR, 9(1), 23-37.

Linyu X., Bing Yu., \& Wencong Y. (2010). A method of green GDP accounting based on eco-service and a case study of Wuyishan, China. Procedia Environmental Sciences, 2, 1865-1872. http://dx.doi.org/10.1016/j.proenv.2010.10.198

Milne, Markus J. (1996). On sustainability; the environment and management accounting. Management Accounting Research, 7, 135-161. http://dx.doi.org/10.1006/mare.1996.0007

Moller, A., \& Stefan S. (2008). The Sustainability Balanced Scorecard as a Framework for Eco-efficiency Analysis. Journal of Industrial Ecology, 9(4), 73-83. http://dx.doi.org/10.1162/108819805775247927

Otte, G. (2008). GHG Emissions Accounting. Accounting, Organizations and Society, 27, 687-708.

Parker, L. (2005). Social and environmental accountability research: a view from the commentary box. Accounting, Auditing \& Accountability Journal, 18(6), 842-60, http://dx.doi.org/10.1108/09513570510627739

Perez, Esther A. (2007). Environmental management systems as an embedding mechanism: a research note. Accounting, Auditing \& Accountability Journal, 20(3), 403-422, http://dx.doi.org/10.1108/09513570710748562

Persson, A. (2004). Environmental Policy Integration: An Introduction. Stockholm Environment Institute, Stockholm.

Stanojevic, M., Vranes, S., \& Go"kalp, I. (2010). Green accounting for greener energy. Renewable and Sustainable Energy Reviews, 14(2010), 2473-2491. http://dx.doi.org/10.1016/j.rser.2010.06.020

Thomas A., \& Karl-Gustaf L. (1999). Pollution tax design and \& Green national accounting. European 
Economic Review, 43(1457), 1474.

United Nations Division for Sustainable Development. (2001). Environmental Management Accounting Procedures and Principles. New York.

Yakhou, M., \& Vernon P, D. (2004). Environmental Accounting: an essential Component of business Strategy. Business Strategy and the Environment, 13, 65-77. http://dx.doi.org/10.1002/bse.395 